\title{
Malaysia's Student Loan Company: Tackling the PTPTN Time Bomb
}

\author{
By Wan Saiful Wan Jan
}

\section{EXECUTIVE SUMMARY}

- The Malaysian National Higher Education Fund Corporation (PTPTN) was set up in 1997. Since then, it has accumulated a massive debt amounting to RM40 billion in principal plus RM13 billion in interest. All these are guaranteed by the Malaysian government.

- It is now the biggest provider of student loans in the country and continues to play a very important role in catalysing socio-economic mobility, especially among the ethnic Malays which is the majority community in the country.

- However, the business model employed by PTPTN is irrational and unsustainable. It borrows from the financial market at, on average, 4 to 5 per cent, and lends to students at 1 per cent. No serious effort has been made to revamp this model, and all public discussions around it have been driven by political populism.

- The biggest challenge is the low repayment rate. This problem has been ignored because Malaysian politicians of all colours have wanted to maintain popularity. Collecting debt is certainly not popular.

- $\quad$ PTPTN, under a new leadership since mid-2018, gathered and developed ideas on how to reform their organization. These ideas have been presented to various levels of government, including to the Cabinet in early 2020.

- PTPTN must be reformed to avoid its debt from inflating further. Whether the Malaysian government has the much-needed political will to push through the reforms is a question yet to be answered. 



\title{
Malaysia's Student Loan Company: Tackling the PTPTN Time Bomb
}

\author{
By Wan Saiful Wan Jan ${ }^{1}$
}

\section{INTRODUCTION}

Malaysia's National Higher Education Fund Corporation (Perbadanan Tabung Pendidikan Tinggi Nasional) is a statutory body responsible for providing study loans to tertiary students, as well as managing education saving schemes. Better known by its Malay language acronym PTPTN, it is also a heavily politicized entity with successive administrations continuously using it as an election sweetener to woo voters.

This essay is an attempt to document PTPTN's history, successes, challenges and future plans. It provides a critical assessment of the student loan body, while at the same time being a distinctive study since this author has access to data on various aspects of the organization's performance by virtue of his position as the current Chairman of PTPTN's Board of Directors, tasked by the Malaysian government to reform the entity.

Following this introduction, the essay will describe the background behind the establishment of PTPTN. The subsequent section will provide some key data to help readers understand the importance of PTPTN, before delving into the problems and challenges faced by the entity, both from the financial and political perspective. The final two sections contain a description of some ideas on PTPTN's future.

\footnotetext{
${ }^{1}$ Wan Saiful Wan Jan is Visiting Senior Fellow at the ISEAS - Yusof Ishak Institute, Singapore, and Chairman of Malaysia's National Higher Education Fund Corp (PTPTN) since 18 June 2018.
} 


\section{BACKGROUND OF PTPTN}

For decades, the Malaysian government has been playing an active role in financing students for higher education. This was the case especially during the period of the New Economic Policy (NEP) from 1971 onwards. A study ${ }^{2}$ conducted in the early 1980s, approximately ten years after the introduction of the NEP, found that, in academic year 1982-83, there were 30,844 students enrolled in the five government universities that existed at that time. Out of these, 20,526 received funding in the form of non-repayable grants or scholarships from a government department or a statutory body. Additionally, an official government report stated that during the same period, there were another 12,800 Malaysian students who received government funding to pursue their studies overseas, at graduate and postgraduate level. ${ }^{3}$ Thus in that period alone, 33,326 students received funding from the Malaysian government to pursue higher education, both in the country and abroad.

One of the key targets of Malaysia's NEP was to restructure society so as to eliminate the identification of race with economic functions. When the NEP was formulated, it was widely assumed that Malaysian businesses were dominated by ethnic Chinese, manual labour by ethnic Indians, and the civil service and political apparatus by ethnic Malays. While this is a simplification of what was in reality a complex situation in a country that had just achieved independence and was still grappling with her multiracial and multicultural society, that broad picture was widely accepted by many. It is therefore not a surprise that higher education funding was also heavily influenced by this racially polarized outlook. In the quest to produce more Malay professionals, government policies around the issuance of the scholarships were also guided by ethnic interests. The proportion of ethnic Malays receiving the scholarships was much higher than for any other group.

\footnotetext{
${ }^{2}$ Ozay Mehmet, Regional Cooperation in High-Quality Manpower Development: The Feasibility of an ASEAN Student Aid Fund (Singapore: RIHED, 1984).

${ }^{3}$ Mid-Term Review of the Fourth Malaysia Plan, 1981-1985 (Kuala Lumpur: Government Printer, 1984).
} 
Malaysia was badly affected by the Asian Financial Crisis that occurred in 1997-98. The strain on finances contributed to, among other things, the government's decision to re-evaluate the role that it should play in higher education financing. Even though the government decided to continue heavily subsidizing the tuition fees of government universities, ${ }^{4}$ the scholarship schemes proved to be an increasingly heavy burden and had to be revamped. The thinking among policymakers at that time shifted from providing scholarships to providing repayable student loans.

It is also important to recognize another development that occurred parallel to the one described above. In 1991, Prime Minister Mahathir Mohamad announced his "Vision 2020", with the aim of making Malaysia a fully developed country by the year 2020. To achieve this vision, access to higher education needed to be greatly expanded, and quickly, so that Malaysia's human capital pool could be enlarged to match the expected increase in demand for talents. Consequently, the Private Higher Education Act was introduced in 1996, enabling private operators, both domestic and foreign, to participate in the provision of higher education in the country. The passage of this Act catalysed the growth of private higher education institutions, thereby creating the much-needed seats for students to pursue their studies. ${ }^{5}$ The government also invested by creating more public universities, but the exponential growth of private colleges and universities meant that the desired university student population could be created without too much pressure

\footnotetext{
${ }^{4}$ The amount of subsidy varies from university to university, but it is generally accepted that about 90 per cent of the public university tuition fee is subsidized by the government, leaving the student to pay only 10 per cent, i.e. if they do not receive other forms of funding to cover that.

${ }^{5}$ For a more detailed treatment of the expansion of higher education provision in Malaysia, see, for example, Morshidi Sirat, "Transnational Higher Education in Malaysia: Balancing Benefits and Concerns Through Regulation", in Transnational Higher Education in Asia and the Pacific, by Futao Huang (Hiroshima: Research Institute for Higher Education, Hiroshima University, 2006), pp. 109-27.
} 
being put on government coffers. Of course, with the increased number of seats, there was also increased demand for financing from sources other than government sponsorship.

The result was the passing of the National Higher Education Fund Corporation Act in 1997, to establish PTPTN as a statutory body. The Act states that PTPTN has three specific functions:

1. to manage the disbursement and repayments of higher education loans;

2. to manage higher education saving schemes; and

3. to implement any other functions as instructed by the government

In its early days, PTPTN was given annual grants by the Malaysian government for it to then lend out to students entering higher education. A total of RM5 billion was received between 1997 and 2002. ${ }^{6}$ But from 2003, the government grants were stopped and PTPTN had to change its business model to one where it borrowed from the market to fund its student loans. The first lenders were state-owned enterprises, namely the two major pension funds in Malaysia-Pension Fund Inc (Kumpulan Wang Amanah Pencen, KWAP) and the Employees Provident Fund (Kumpulan Wang Simpanan Pekerja, KWSP). ${ }^{7}$ Subsequently, PTPTN started to borrow from commercial banks by issuing Islamic bonds or sukuks, all of which are completely backed by government guarantees. This change in PTPTN's business model-from receiving government grants to borrowing from the financial market - is a major contributor to the problems faced by PTPTN today, an issue which will be discussed later in this essay.

Since its inception, PTPTN has provided loans to some 3 million students, disbursing more than RM56 billion over the twenty-three years.

\footnotetext{
$6 \mathrm{https} / / /$ www.theedgemarkets.com/article/full-conversion-islamic-finance-end2010-says-ptptn (accessed 30 December 2019).

${ }^{7} \mathrm{KWAP}$ is responsible for public sector pensions while KWSP handles private sector pensions.
} 
Its mandate is to lend to students entering local institutions only. Those planning to pursue their studies abroad are not eligible for PTPTN loans. Today, on average between 160,000 to 180,000 students become new PTPTN borrowers every year, costing PTPTN between RM3 billion to RM3.5 billion annually. Even though the number of borrowers and the amount disbursed have increased significantly over the years, one thing that has remained constant is the unwritten role of PTPTN to catalyse social mobility especially among ethnic Malays, by ensuring the availability of funds to pay for their higher education costs. When the first business plan for PTPTN was drafted, that pro-Malay agenda was clearly at the back of the minds of the planners. ${ }^{8}$

To fulfil that unwritten role, PTPTN intentionally makes the application and approval processes as easy as possible, since it is assumed that most Malay applicants, especially those from rural areas, would not qualify if stricter criteria like those commonly used by banks to issue loans were employed. This results in a situation where almost 95 per cent of those who apply will get the loans. Applicants are not required to provide guarantors and the cost of borrowing is only 1 per cent. ${ }^{9}$ The application process is also rather straightforward. Everything can be done online, and, once the loan is approved, the fund is paid directly into the student's bank account. The amount of money that each student can borrow varies depending on the level of study and the student's parental income, as shown in Tables 1 and 2. It should be noted that the loan amount is determined by PTPTN and is not necessarily related to the tuition fee.

\footnotetext{
${ }^{8}$ Interview with Dato Hassan Harun on 24 December 2019. Dato Hassan was a member of the Economic Bureau of the United Malays National Organization (UMNO) party, and one of the key individuals involved in setting up PTPTN. He was also among the first Board members of PTPTN when it was set up.

${ }^{9}$ PTPTN offers Islamic-based loans and does not charge interest, but charges ujrah instead, which is a shariah-compliant service charge.
} 


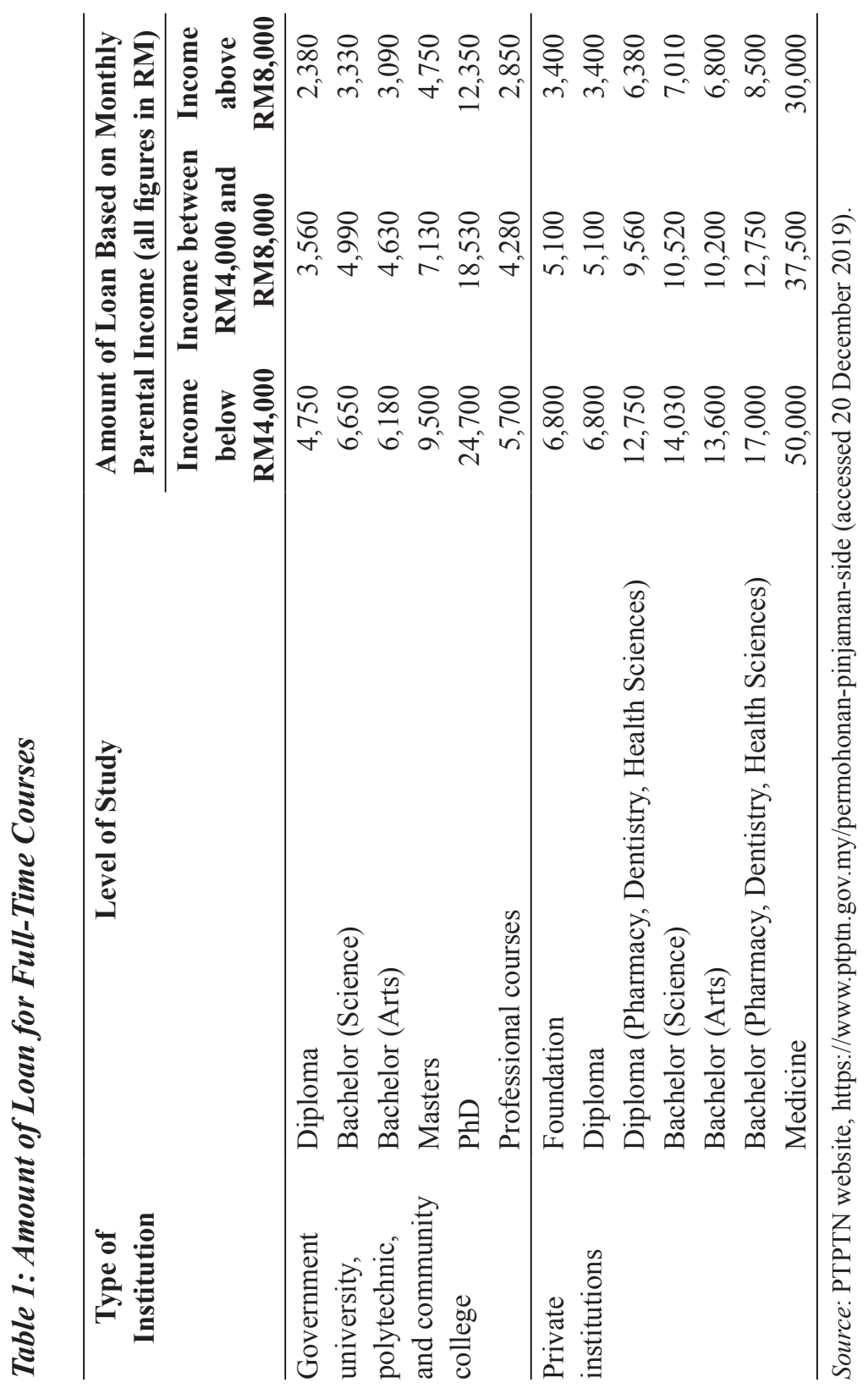


Borrowers are given a twelve-month grace period after graduation before they are obliged to start repayment. This grace period is meant to provide respite to borrowers while they search for employment. The amount of repayment is determined by PTPTN, based on the amount of loan taken and the period of time the borrower agreed to make the repayment. At the time this essay was written, the amount ranges from RM92 to more than RM250 per month, as shown in Table 3.

Table 2: Amount of Loan for Part-Time Courses ${ }^{a}$

\begin{tabular}{llc}
\hline Type of Institution & Level of Study & $\begin{array}{c}\text { Maximum Amount } \\
\text { per annum } \\
\text { (RM) }\end{array}$ \\
\hline Public university & Diploma & 4,750 \\
and polytechnic & Bachelor & 6,180 \\
& Masters & 9,500 \\
& PhD & 24,700 \\
& Professional courses & 5,700 \\
\hline Private institutions & Diploma & 5,050 \\
& Bachelor & 5,470 \\
\hline
\end{tabular}

Note: a. Only available for study at selected institutions.

Source: PTPTN website, https://www.ptptn.gov.my/permohonan-pinjaman-side (accessed 20 December 2019).

Table 3: Repayment Rate of PTPTN Loans

\begin{tabular}{lcc}
\hline Loan Sum (RM) & $\begin{array}{c}\text { Repayment Period } \\
\text { (months) }\end{array}$ & $\begin{array}{c}\text { Repayment Amount } \\
\text { (RM) }\end{array}$ \\
\hline Below 10,000 & 60 & Up to 175 \\
$10,000-22,000$ & 120 & $92-202$ \\
$22,00-50,000$ & 180 & $141-320$ \\
More than 50,000 & 240 & More than 250 \\
\hline
\end{tabular}

Source: PTPTN Public Consultation Paper, April 2019. 


\section{KEY DATA ON PTPTN LOANS}

PTPTN plays a key role in ensuring that students who fulfil the qualification requirements to enrol into higher education are not prevented from doing so by their financial situation. It has already been stated above that PTPTN provides financing to between 160,000 to 180,000 students per year. This is a major jump from the approximately 25,000 to 35,000 students per annum receiving government funding in the 1990s prior to the establishment of PTPTN.${ }^{10}$ In total, more than 3 million students have benefitted from PTPTN loans since its inception, with the total funds disbursed amounting to more than RM56 billion.

On average, 55 per cent of the borrowers are from the poorer segment of society, or what is commonly called in Malaysia as the "Bottom 40 per cent" or B40 group, but because the amount of loans allocated for this group is the highest, they receive 60 per cent of the amount disbursed (see Figure 1). The Middle 40 per cent group or M40 makes up 38 per cent of the borrowers, receiving 35 per cent of the amount disbursed. While the Top 20 per cent group or T20 makes up only 7 per cent of borrowers, with just 5 per cent of the amount disbursed going to them. This means that by far, the biggest beneficiary of PTPTN loans are borrowers from the lower income segment. Without PTPTN, this group may face real difficulty in financing their studies because government and private sector scholarships are scarce, and they are unlikely to obtain loans from commercial banks where the process tends to be stricter and the costs higher.

In terms of ethnicity, 66 per cent of the borrowers are ethnic Malays, 20 per cent ethnic Chinese, and 6 per cent ethnic Indians, while 8 per cent are from other ethnic groups (see Figure 2). This again highlights the importance of PTPTN. Ethnic Malays are the biggest recipient of its loans, and this thereby contributes directly to Malaysia's long-standing attempt to produce more Malay graduates and professionals. However,

${ }^{10}$ TV interview with PTPTN Chairman Wan Saiful Wan Jan, broadcasted on channel RTM1's Politikonomi, 9.00 p.m., 25 December 2019. 
Figure 1: Percentage Breakdown of Approved Loans by Income Level, 2014-18

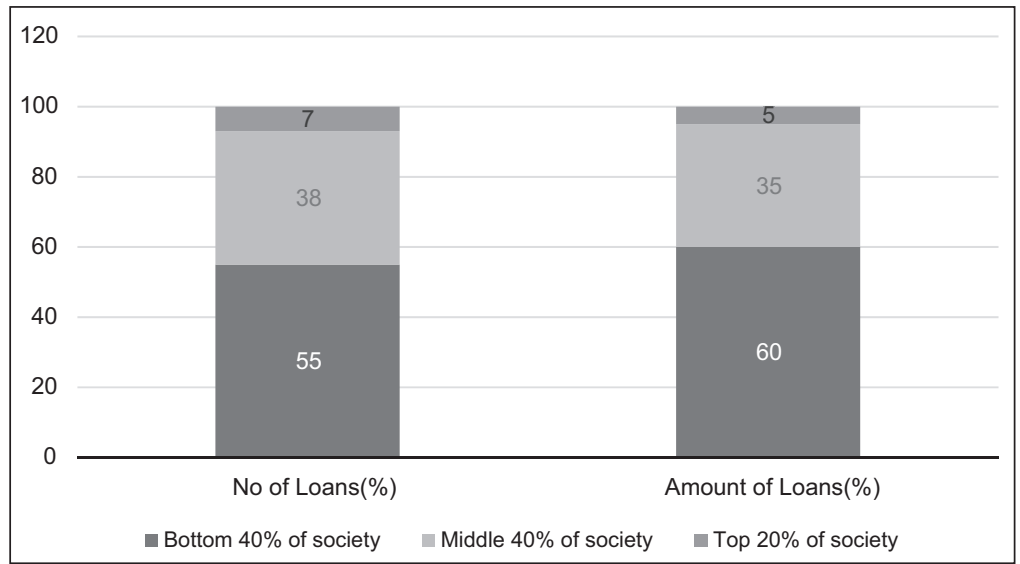

Source: PTPTN Public Consultation Paper, April 2019.

Figure 2: Breakdown of Borrowers by Ethnicity, 2014-18

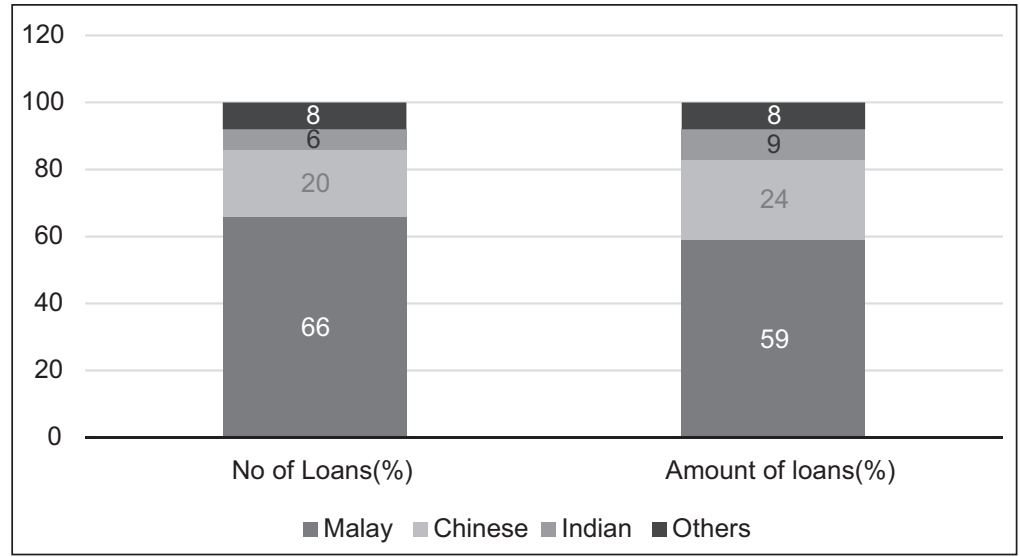

Source: PTPTN Public Consultation Paper, April 2019. 
since more non-Malays attend private institutions that charge higher fees, the amount disbursed to them are slightly higher than for ethnic Malays. Figure 3 shows that half of the loans go towards funding students enrolled at the Bachelor's degree level, while 46 per cent is for those studying at Diploma level. This implies that for 96 per cent of the borrowers, the loans are used to fund their first higher education qualification. Combining this with the ethnic breakdown, PTPTN clearly has an important role to play in ensuring that ethnic Malays have equitable access to their first higher education qualification, which in turn could very well be the pivotal step for their upward social mobility.

As shown in Figure 4, the majority (63 per cent) of PTPTN loans has gone to students attending government universities. Only 37 per cent of the loans went to students attending private universities and colleges. But

Figure 3: Breakdown of Loans by Education Level, 2014-18

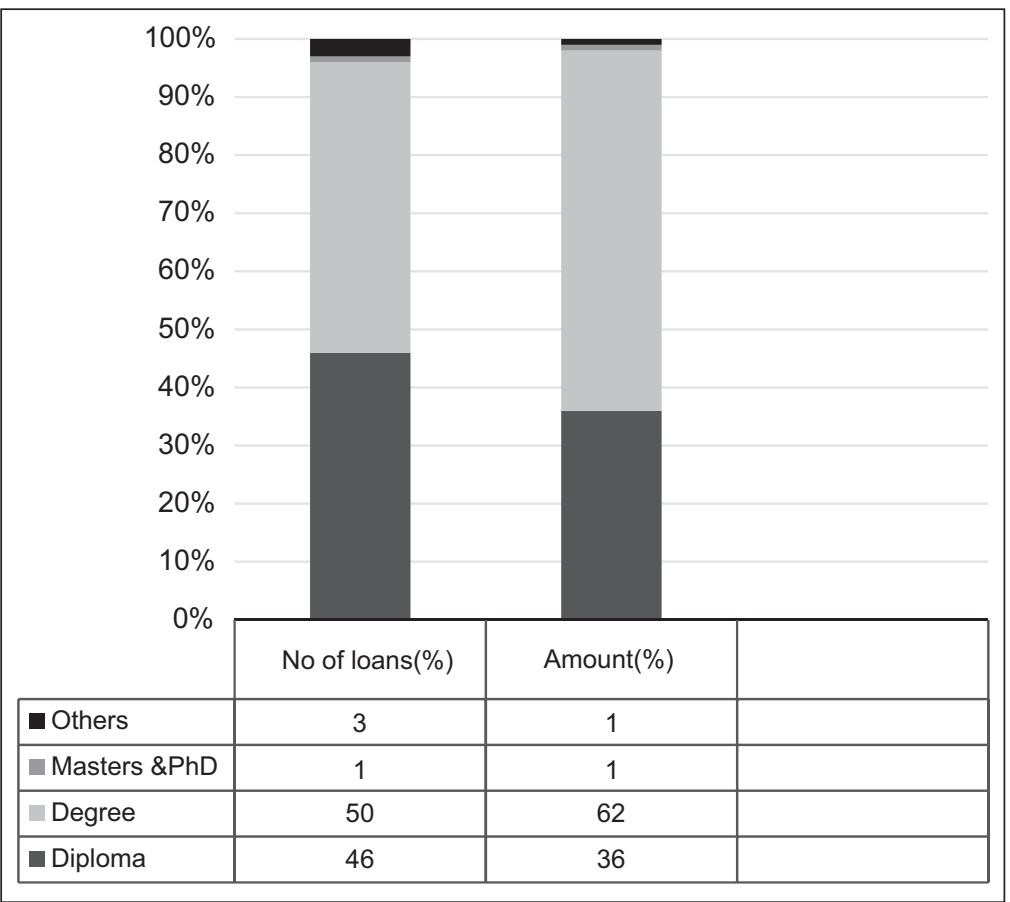


Figure 4: Breakdown of Loans by Type of Institutions, 2014-18

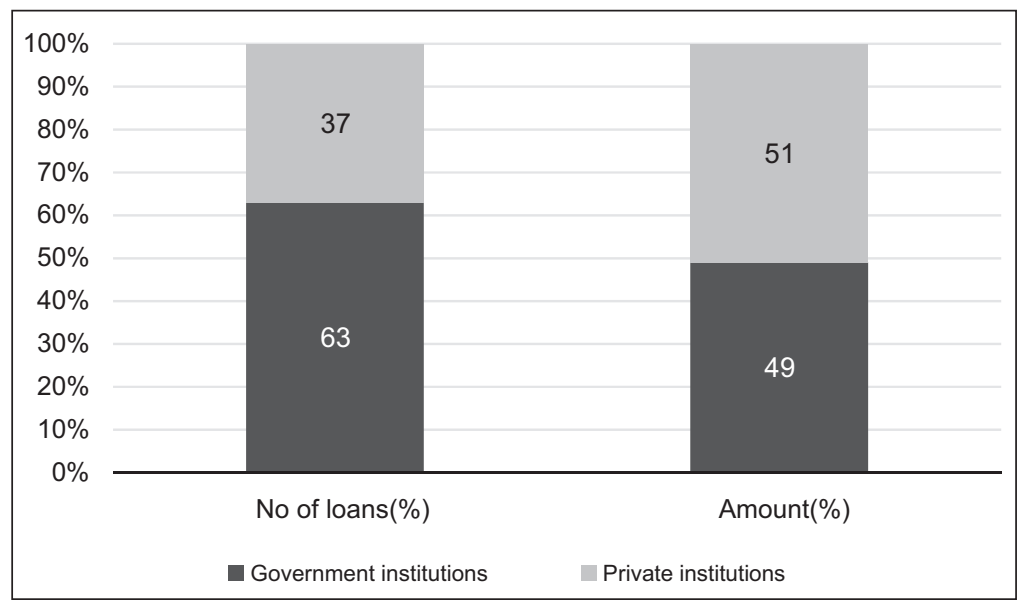

Source: PTPTN Public Consultation Paper, April 2019.

since tuition fees at government institutions are heavily subsidized, the amount loaned to this group is just 49 per cent of the amount disbursed. Interestingly, this means that, in terms of the amount disbursed, the distribution between government and private institutions is now almost equal.

Having said that, a study by Ong et al. ${ }^{11}$ found that if the amount disbursed is traced back all the way to 1997, the distribution had not always been equal. Instead, there was a significant jump in the amount disbursed for students enrolling into private institutions, especially in the mid-2000s period. This period also saw an increase in the numbers of private institutions. In 1997, there were only four private universities whose students qualified to receive PTPTN loans, but by 2019 , the

${ }^{11}$ Ong Kian-Ming, Jonathan Yong, Chew Khai-Yen and Dickson Ng, "The Sustainability of the PTPTN Loan Scheme", Penang Institute, December 2016. 
number spiked to 66 private universities, 31 private university colleges, and 329 private colleges. ${ }^{12}$ This situation led some to accuse PTPTN of feeding the mushrooming of private higher education institutions in Malaysia by creating an artificial supply of money to pay the tuition fees and associated costs. As the argument goes, without PTPTN, many of the private institutions would not have been set up at all, and the major reason for their continued existence is the availability of easy money from PTPTN to pay for their students. ${ }^{13}$

In late 2019, PTPTN commissioned a study to understand their borrowers better. A randomized and representative sample of 2,500 borrowers were asked to complete a questionnaire, with their identities kept anonymous for more honest answers. Responses were received from 1,866 borrowers. It was found that almost all borrowers in the B40 category are not paying back their loans. As shown in Figure 5, a total of 87.7 per cent ${ }^{14}$ of borrowers in this study earn below RM4,000 per month after graduation, putting them in the B40 group. It was also found that, 97 per cent of defaulters belong to the B40 group (Figure 6). This is a staggering number, indicating the possibility that those who are not paying are not necessarily not doing so intentionally, but because they may have real difficulty paying the instalments due to bad personal financial situations.

To further gauge why some borrowers are not paying consistently, the defaulters were asked to state the main reason why they do not pay. The findings are summarized in Figure 7, which clearly shows that financial difficulty has a big influence on borrowers' ability to pay. The top three

\footnotetext{
${ }^{12}$ Presentation by PTPTN Chairman Wan Saiful Wan Jan at the ISEAS - Yusof Ishak Institute, Singapore, 18 September 2019.

13 See, for example, https://kprumalaysia.org/2013/05/03/free-education-inmalaysia-not-a-fantasy/ (accessed 29 December 2019).

${ }^{14}$ This number is higher than what was captured by PTPTN when they conducted their data gathering exercise in mid-2018, as described in the next section. In that exercise, 68 per cent of borrowers were found to be earning below RM4,000 per month. The difference could be due to the fact that the 2018 exercise did not include those who were self-employed.
} 
Figure 5: PTPTN Borrowers by Income Level after Graduation $(n=1,866)$

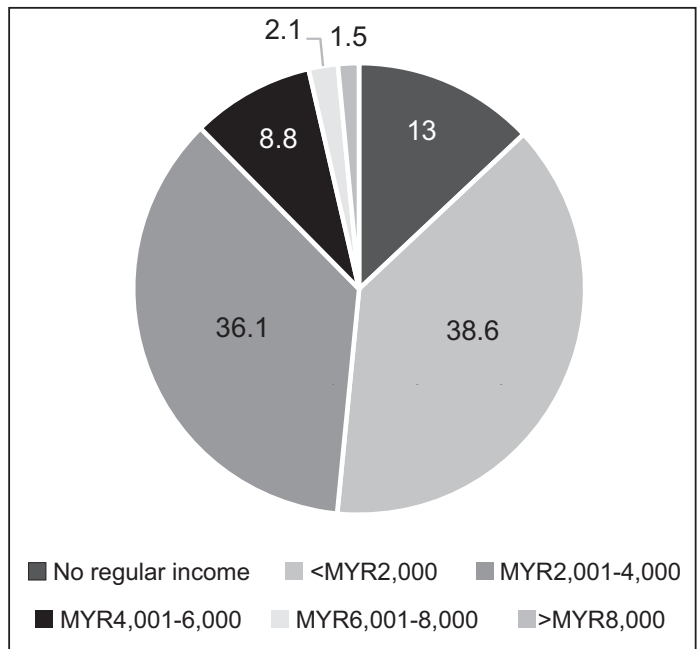

Figure 6: Income Distribution Among Defaulters ( $n=551)$

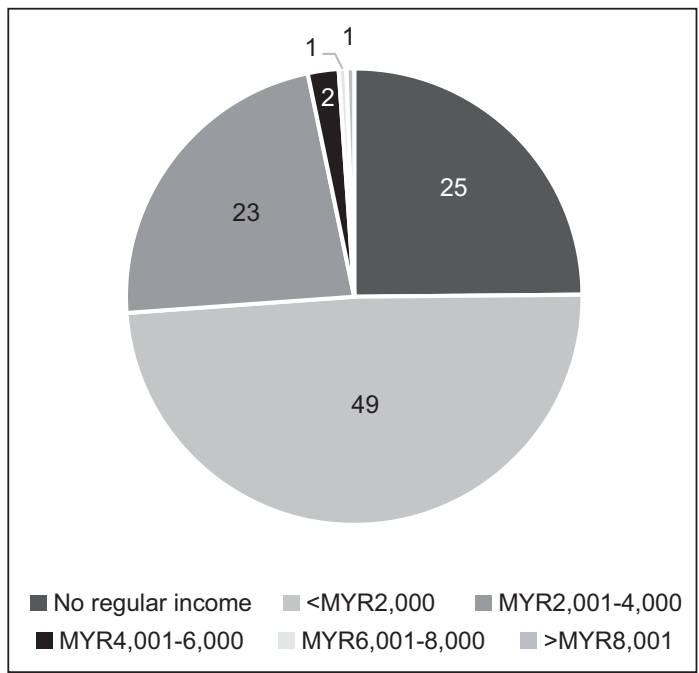


Figure 7: Reasons for Default $(n=551)$

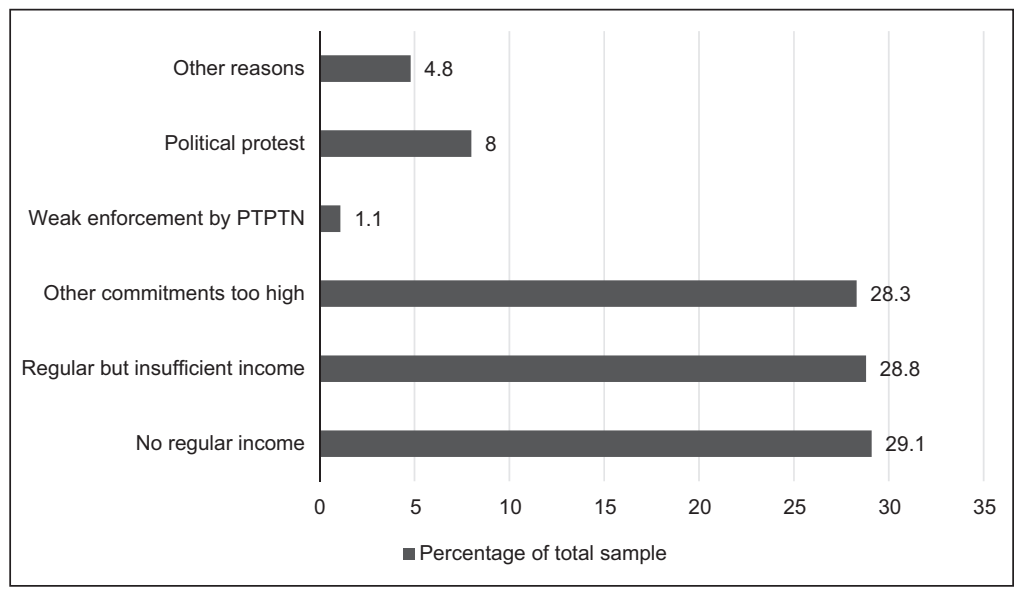

reasons given are all related to personal financial challenges faced by the borrowers themselves, with 29.1 per cent saying that they do not have any regular income, 28.8 per cent saying that they do not have sufficient income, and 28.3 per cent regretting that their other financial commitments are too high to allow them to repay their student debt. All these imply that PTPTN's financial challenge is not necessarily due to how the organization is run, but is actually heavily influenced by the wider economic structure of the country - a large number of graduates seem to be stuck in low-paying jobs, or worse, remain unemployed.

\section{THE MAIN CHALLENGES}

The business model employed by PTPTN is certainly one that has created a very heavy financial burden on itself as well as on the Malaysian government. Internal PTPTN data from 2019 show that the organization has RM40 billion in debt, plus another RM13 billion in interest that it is responsible for. The debt arose because of PTPTN's irrational business model to "borrow at a high rate and lend at a low rate". PTPTN borrows from the financial market at, on average, 4 to 5 per cent interest rate, while it charges borrowers just 1 per cent. The difference has been 
compounding year-on-year for twenty years, contributing significantly to PTPTN's mountain of debt. This is a major challenge for the government because all the debt is backed by government guarantees.

But perhaps the root cause of PTPTN's challenges is the tendency of Malaysian politicians of all colours, and many among the lay public too, to look at PTPTN with a heavily politicized lens. Serious analysis of how to solve PTPTN's mounting debt problems is scarce, but political debate about it is widespread and can be found very easily. For example, in the last general election in 2018, all three main coalitions put forward populist promises related to PTPTN, and none talked about how to solve its debts. All the political promises revolved around enabling borrowers to not pay or pay only a reduced amount, ${ }^{15}$ neglecting the debts saddling PTPTN and its low repayment problem. In hindsight, it was clear that the consideration at that time was not so much about ensuring PTPTN's sustainability or how to reduce its debt burden, but more about attracting the votes of its borrowers regardless of the financial implications on PTPTN or the government.

This populist approach is not unique to the last general election. Rather, populism has been the guiding principle for policymakers and politicians since the day PTPTN was established. Successive administrations have been very reluctant to take any action on delinquent borrowers, fearing political reprisal through the ballot box. The outcome is a situation where, despite the dire need to collect repayments, PTPTN has been rather lax on collection and recovery. A staggering 51 per cent of borrowers are either paying inconsistently or have never paid at all. As at the end of 2018, the amount of repayment received is only 58 per cent of the amount scheduled to be repaid. And the amount outstanding has reached RM6.3 billion, with 68 per cent of the defaulters having not paid for more than a year. ${ }^{16}$ Figure 8 summarizes the situation. However,

\footnotetext{
${ }^{15}$ Barisan Nasional promised to offer discounts on repayment, Pakatan Harapan wanted to defer repayment for low-income borrowers, while PAS wanted to abolish PTPTN altogether.

${ }^{16}$ Presentation by PTPTN Chairman Wan Saiful Wan Jan at the ISEAS - Yusof Ishak Institute, Singapore, 18 September 2019.
} 


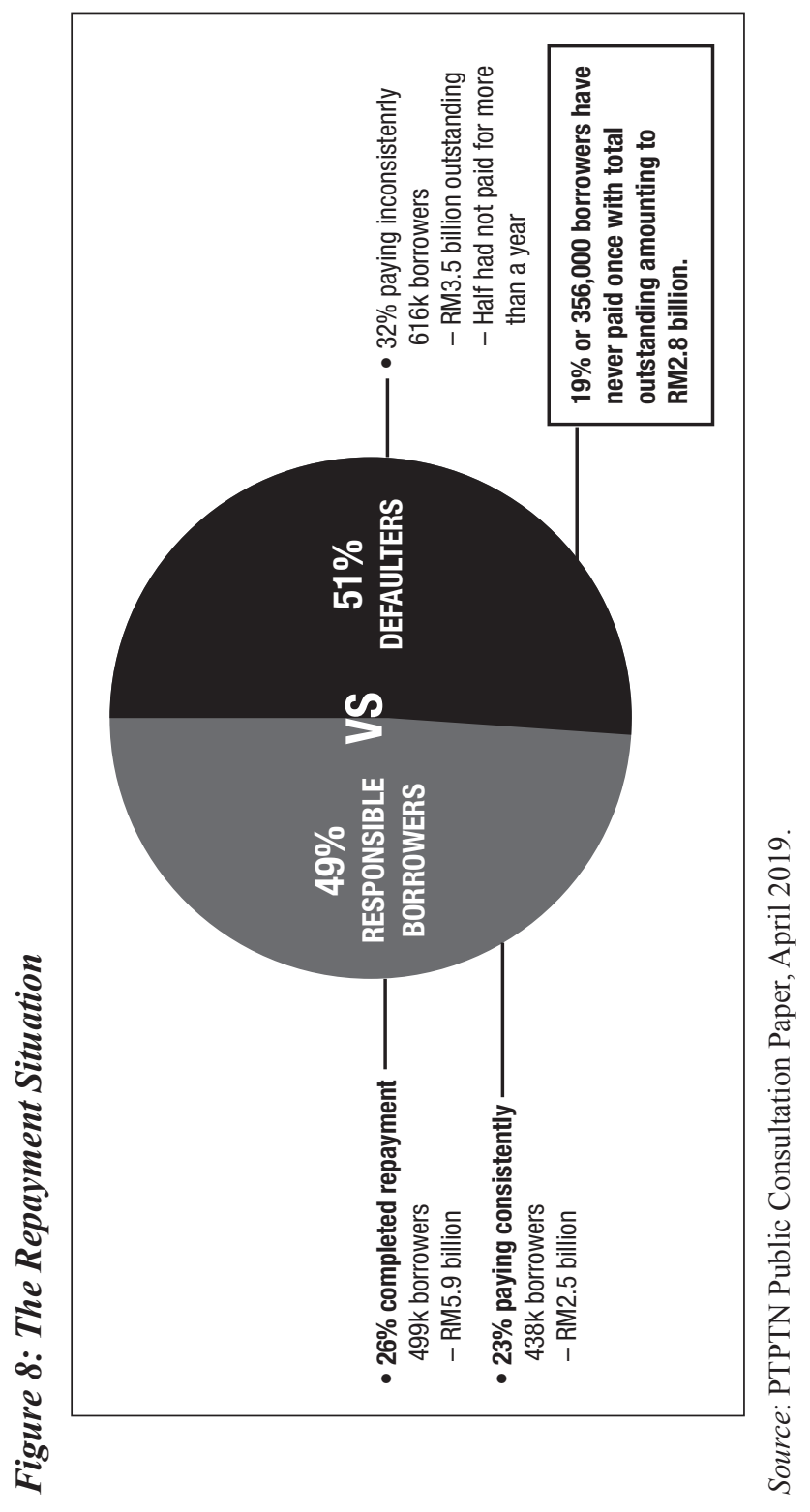


despite these financial challenges, hardly any action has been taken on the defaulters, probably because the borrowers are also young voters.

In 2014, as a result of the long-standing populist attitude among policymakers, PTPTN actually faced a major cashflow crisis. But the crisis was very carefully hidden from public knowledge by the government at that time. As stated in Ong et al., "According to figures from the 2012 to 2015 annual reports, the accumulated repayment rate, which, at 54.6 per cent in 2011, was not high to begin with, had dipped to 45 per cent in 2014. ${ }^{\prime 17}$ PTPTN found itself in a situation where it could not afford to issue the same number of new loans as it previously could. Almost 50,000 new applicants were at risk of being rejected. To avoid such a situation, PTPTN took the drastic step of reducing the amount of loans given out to all students attending government institutions by 5 per cent and private institutions by 15 per cent. ${ }^{18}$ The action may have enabled PTPTN to fund all those who qualified that year, but the low repayment rate problem continues to be swept under the carpet.

Since PTPTN does not receive any grants from the government and its business model is borrow-in-order-to-lend, the low repayment rate forces PTPTN to borrow even more from the financial market. This creates a vicious cycle wherein PTPTN borrows more and more money from commercial banks not just to fund new loans given to students, but also to pay debts that have reached maturity. PTPTN projects that if it continues to operate using the current business model, its debt principal will increase from the current RM40 billion to RM55 billion in 2030 and RM76 billion in 2040, while its interest burden will spike to RM24 billion in just ten years. ${ }^{19}$

The situation becomes more complex when PTPTN is regarded not as a financial institution with a purely commercial function, but one that also has a social purpose and duty to guarantee the production of

\footnotetext{
${ }^{17}$ Ong Kian-Ming, et al., "The Sustainability of the PTPTN Loan Scheme”.

${ }^{18}$ PTPTN Public Consultation Paper, April 2019.

${ }^{19}$ Calculation using PTPTN internal data, 2019.
} 
Malaysia's future human capital, and to support social mobility in the country, especially among the Malays. The Malaysian Higher Education Blueprint 2015-25 projects that the number of students enrolling into higher education institutions will reach 250,000 per year by 2040 . PTPTN therefore must prepare itself for an even bigger number of borrowers, requiring an even higher amount of money to be borrowed from the financial market. With the current business model, it is almost impossible to envisage the ending of the vicious cycle, making PTPTN a time bomb that needs to be reformed urgently.

The situation eventually led the government to openly admit that PTPTN's business model is problematic and unsustainable. In a parliament session in October 2019, the Minister of Education announced that PTPTN's way of conducting business needed to be revamped. ${ }^{20}$ This announcement was long overdue, and it opens the door for significant changes to be undertaken.

\section{REFORM EFFORTS ${ }^{21}$}

Efforts to persuade the government to revamp PTPTN's business model actually started in late 2018, almost a year before the Minister made his announcement in parliament. Various discussions took place between PTPTN and higher authorities at the Ministry of Education, the Ministry of Finance, and even the Prime Minister's Office, regarding the speeding up of the reform process and the removal of bureaucratic barriers to change. Throughout, political decision-makers were still shrouded by the desire to remain popular, and this created lengthy internal disagreements on whether the government should risk becoming unpopular in order to do

20 https://www.thestar.com.my/news/nation/2019/10/29/dr-maszlee-committeeto-be-formed-to-find-a-new-model-to-replace-ptptn (accessed 27 December 2019).

${ }^{21}$ This section is mainly based on internal discussions ongoing within PTPTN. The points elaborated in this section are restricted only to information that have already been released to the public and are unclassified at the time of writing. 
the right thing, or to prioritize popularity over responsible management of the country's finances. Prime Minister Mahathir Mohamad was a staunch advocate of a principled approach and PTPTN did attempt to fulfil his vision, but other ministers did not always see eye to eye with him, and this resulted in a stalemate and lack of clarity over the direction that PTPTN should take.

In discussing the efforts to reform PTPTN, it is necessary to understand the political context first. In the run-up to the 14th General Elections (GE-14) held on 9 May 2018, the Pakatan Harapan (PH) coalition made four promises related to PTPTN in its manifesto. First, it would abolish the international travel restrictions imposed on borrowers who defaulted. This was delivered within just weeks of PH taking over the government, benefitting 429,945 borrowers whose names were removed from the blacklist. Second, it wished to encourage employers to assist their employees who have remaining loans with PTPTN. This was implemented from 1 January 2019, when a scheme was introduced so that employers qualify for tax exemption for any amount they allocate to pay for their employees student loan. Third, it wanted to reward good academic performance by students from low- and middle-income families by converting their loans to non-repayable scholarships. This too was delivered from 1 January 2019. Thus, three out of the four promises were delivered within just six months of the new PTPTN Board taking over. ${ }^{22}$

The biggest challenge, however, is the fourth manifesto promise which is to allow those earning below RM4, $000^{23}$ per month to defer their repayments until such times when they earn above that sum. When the new leadership team took over after GE-14, they discovered that PTPTN does not have any data about the income levels of their borrowers. This made it impossible to decide who should get the exemption and who should not.

\footnotetext{
${ }^{22}$ https://www.thestar.com.my/news/nation/2019/12/26/three-out-of-fourpromises-on-ptptn-fulfilled-says-wan-saiful (accessed 20 February 2020).

${ }^{23}$ The figure RM4,000 was selected because this is the threshold for the "Bottom 40 percent (B40)" category.
} 
A major data collection exercise was conducted in the third quarter of 2018, and this revealed a major surprise. It has always been assumed that attending higher education would push students up the socioeconomic ladder, and therefore the number of borrowers earning below RM4,000 would be low. But this study revealed, for the first time, that the percentage of borrowers earning below RM4,000 is in fact very high, at 68 per cent. If as many as 68 per cent of borrowers are exempted from repayment, PTPTN will not have enough funds to continue giving loans to new borrowers because there will be a major drop in the collection amount (see Figure 9). As described in the previous section, another study was conducted in late 2019 and it showed an even higher number of borrowers, 87.7 per cent, earning below RM4,000.

Regardless of which figure is used, if the fourth manifesto promise were to be implemented, it is clear that without first securing additional and new funds, PTPTN will not be able to afford lending to the expected 160,000 to 180,000 new borrowers every year. The number of new borrowers then would have to be drastically reduced. The PTPTN Board, however, decided against limiting the number of borrowers since that would in turn limit the supply of future talents for the Malaysian job market.

Subsequently PTPTN held a public consultation to elicit feedback on how it should move forward, starting from 16 May 2019 for a onemonth period. A consultation paper was released, and that was the first time in PTPTN's history that such a frank assessment of the entity was published for public consumption. Together with detailed data on the organization's financial situation and bleak projections, the consultation paper also clearly states that "the escalating financial strain on PTPTN, the Government and taxpayers is already unsustainable. There is a high risk that the PTPTN student loan financing facility will eventually collapse if nothing changes... The continuing low repayment performance coupled with increasing financial obligations will cause PTPTN to be insolvent." ${ }^{24}$

\footnotetext{
${ }^{24}$ PTPTN Public Consultation Paper, April 2019.
} 


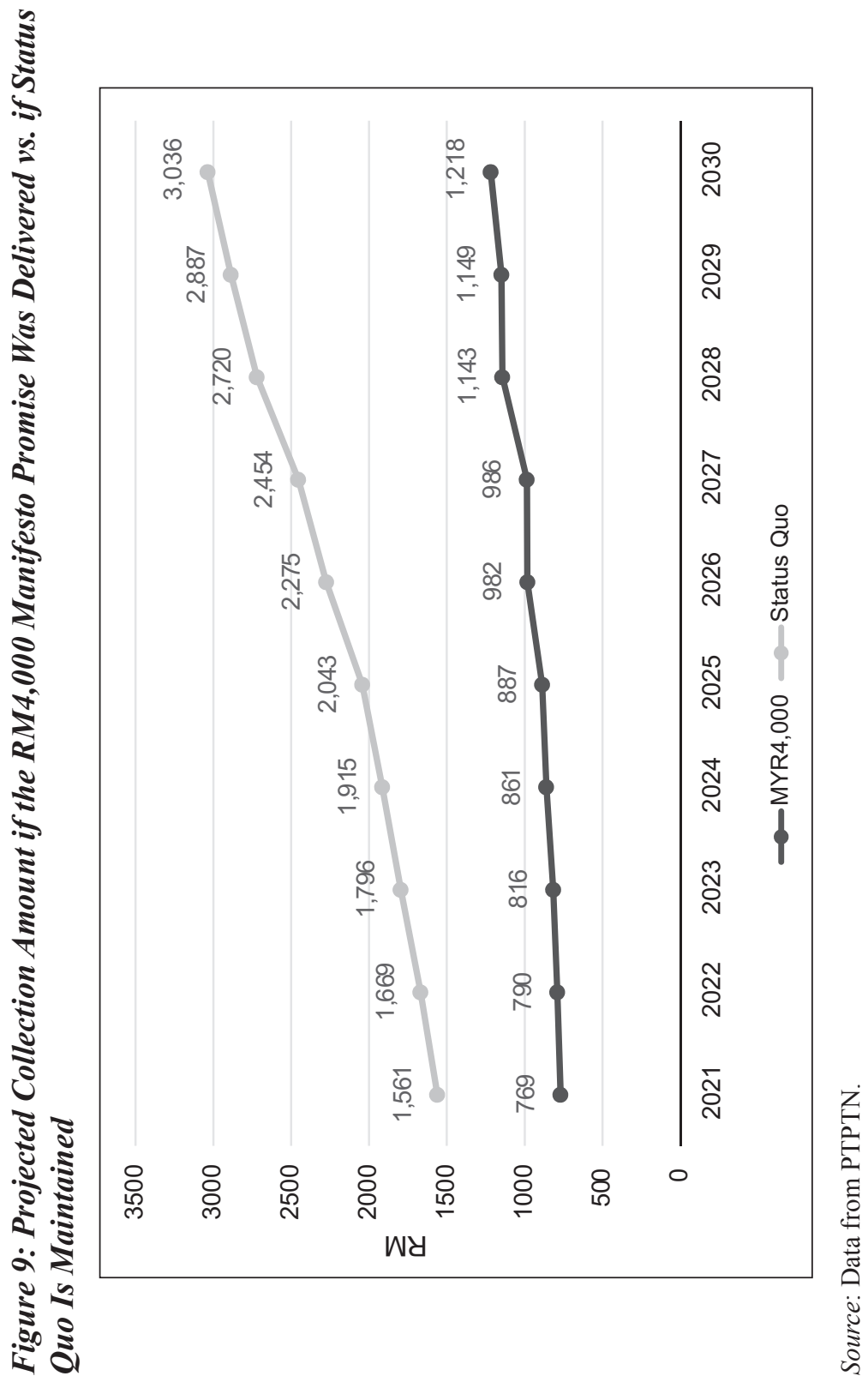


The consultation received an overwhelming response. When it closed on 13 June 2019, PTPTN had received a record high of 34,469 submissions with feedbacks and new ideas, in addition to comments collected from the five townhalls conducted in the cities of Kuala Lumpur, Penang, Kuala Terengganu, Kota Kinabalu and Kuching. A Facebook Live session was also held as part of the process, and this attracted more than 25,000 viewers. Public interest in the future of PTPTN is apparent. PTPTN then analysed the inputs and submitted a report to the Minister of Education in July 2019.25

At the time of writing this essay, the Minister of Education has not yet officially responded to PTPTN's submission. However, within the government, there are two broad schools of thought on how to tackle the PTPTN issue. Both believe that the government must continue to offer an affordable higher education student loan scheme and that the government also has a duty to help reduce the financial burdens faced by existing borrowers. But they differ in the details of how to achieve these ideals and how far-reaching the reforms should be.

The first school of thought focuses on changing how PTPTN works, without asking for major structural reforms. There are four areas that this group most commonly talks about:

i. Salary deduction by employers: The main emphasis is on improving collections of repayments by introducing a salary deduction scheme. PTPTN has the legal power to compel employers to deduct employee salaries for the purpose of loan repayment. ${ }^{26}$ This power has never been exercised, but the 2019 public consultation found that support for such a scheme is high. Borrowers see salary deduction as a convenient way to pay their loans, and they are open to it being made more widely available. Additionally, by mandating employers to assist

\footnotetext{
${ }^{25}$ https://www.thestar.com.my/news/education/2019/07/07/ptptn-publicconsultation-report-to-be-submitted-to-ministry (accessed 20 December 2019).

${ }^{26}$ National Higher Education Fund Corporation Act 1997.
} 
PTPTN — similar to how Malaysia's Inland Revenue Board requires employers to deduct employee salaries for income tax purposes - it is envisaged that the percentage of borrowers making regular payments will improve significantly from its low current rate of 49 per cent.

ii. Income-contingent repayment: To make the repayment more affordable, it has been proposed that the salary deduction scheme should be coupled with an income-contingent loan repayment scheme akin to the one implemented in Australia now. In such a scheme, borrowers repay their loans at a rate dependent on how much they earn. Similar to progressive income tax, those with lower income pay less, while higher income earners pay more. The actual repayment rate is still being internally discussed but it is expected that PTPTN itself will propose to the government that, if this scheme is adopted, the ceiling rate should be set at 8 per cent of a borrower's monthly income, and borrowers will only be required to pay when their monthly income goes above a certain threshold. This scheme is assumed to be more fair and affordable than the existing arrangement that disregards a borrower's income. It lessens the burden of those on the lower end of the income spectrum, while compelling those who can afford it to pay a higher amount.

iii. Stricter enforcement against delinquents: Once ease of payment and affordability is built into the scheme, it is also argued that stern action must be taken against those who can afford to pay but still refuse to do so. For the twenty-two years that PTPTN has existed, it has almost always avoided taking legal action against delinquent borrowers, in order to avoid political backlash. But if an improved and more affordable scheme is introduced, the case for stricter enforcement becomes stronger. Additionally, in an inter-agency workshop organized by PTPTN in mid-2019, it was revealed that 55 per cent of PTPTN borrowers also have loans from other financial institutions. From this group, 99 per cent of those who are delinquent in paying their PTPTN loans are very disciplined in paying their debt to the other institutions. The inference is that they ignore their PTPTN loans not because they cannot afford it - since they regularly pay their other debts - but simply because they take their obligation to PTPTN lightly. Hence stricter measures are required to handle this group. 
iv. More assistance for borrowers: More needs to be done to help borrowers who truly cannot afford to pay. Top on the list is the need to help graduates who are still unemployed to obtain jobs. Graduate underemployment and unemployment are issues that have existed for quite some time in Malaysia. A news report states that annually, Malaysian government and private universities "produce something like 51,000 graduates a year, but nearly 60 per cent remain unemployed one year after graduation, according to a study in 2018 conducted by the Ministry of Education Malaysia's Graduate Tracer Study". ${ }^{27}$ It is only logical that if the graduates are not assisted in getting jobs, they will continue to have problems repaying their PTPTN loans.

The second school of thought believes that while all of the above are important and must be done, there is an urgent need to structurally reorganize PTPTN so that its forward movement is not hindered by historical baggage, and, parallel to that to nudge society away from dependency on debt to a culture of saving for education. The reforms suggested by this group are more far-reaching and will be more challenging to implement, as described below.

i. Major reorganization: As it stands, PTPTN handles three different activities, namely issuance of loans and collection, recovery of arrears, and savings and investment management. Although these three activities are quite distinctive, in PTPTN today, they are all run under one roof, thus preventing real accountability when it comes to measuring performance. Strong or weak performance in one area will have an effect on everybody in PTPTN, including those working in a completely different area. For example, the savings and investment management arm of PTPTN regularly produces good returns for its depositors. But their performance is hardly recognized by the public, and many Malaysians still do not even realize the

27 https://www.nst.com.my/news/nation/2020/02/562309/more-and-moregraduates-are-facing-unemployment-malaysia (accessed 3 February 2020). 
existence of PTPTN's savings and investment products because almost all discussions are overly focused on lending and collection. Additionally, dealing with delinquent borrowers who have arrears requires a recovery-type approach that, as described above, would involve stricter enforcement. This is an approach that is very different from that used for those who pay their dues regularly.

The three activities are distinctive enough to warrant a major reorganization of PTPTN. The current suggestion therefore is to either break PTPTN into three different entities governed by their own respective Boards or by one "parent" Board, or create three distinct strategic business units or subsidiaries reporting to a group CEO. It is believed that by doing this, each function can specialize in their roles, and the performance of one will not hinder the other from moving forward. Implicit in this suggestion is the assumption that the low collection rate has a negative impact on all other functions of PTPTN, and a separation would allow for the issuance of new loans and its collection, as well as the management of depositors funds, to undergo a fresh restart.

ii. Create a savings culture: An important follow-through from the reorganization is the need to promote PTPTN's education savings and investment products. By encouraging Malaysians to save for their children's future education, the dependency on debt to fund higher education studies can be reduced. In fact, PTPTN has introduced several initiatives to encourage people to save more. In 2019, it was announced that depositors will enjoy tax relief for the first RM8,000 they deposit into PTPTN's education savings scheme, up from RM6,000 in previous years. On top of that PTPTN, allocates more than RM1.1 million for a "lucky draw" programme, in which depositors are randomly selected to win attractive prizes every quarter.

Depositors also qualify for free shariah-compliant life insurance if they fulfil certain criteria determined by PTPTN. Acknowledging that parents from low-income households may not be able to save large amounts, PTPTN relaunched a matching grant programme that was first introduced in 2003, aimed at depositors in the B40 category. The matching grant provides a ringgit-to-ringgit benefit for 
B40 depositors who fulfil certain conditions, up to a maximum of RM10,000. Under this scheme, if a depositor saves RM10,000 over a ten-year period and their child obtains a seat in a higher education institution, PTPTN will match their savings with another RM10,000, allowing the depositor to withdraw RM20,000 in total. This is a most generous matching grant scheme, with a 100 per cent return over ten years, putting PTPTN's products among the best savings products in the country, especially for lower-income earners.

Another important aspect of any savings and investment product is the dividend. For the past five years, the average dividend paid by PTPTN is 4 per cent. Since PTPTN provides a savings scheme with no mandatory time commitment, the dividend rate is competitive compared to other savings account offered by commercial banks. But internally, PTPTN believes that the dividend can be improved if their investment portfolio is diversified. At the moment, PTPTN is only allowed by the Ministry of Finance to place their funds in fixed deposit accounts offered by local banks. This is considered as least risky. But PTPTN has requested permission from the Ministry of Finance to explore investment opportunities that can create better returns, so that PTPTN can offer higher dividends to their depositors. This too is part of the attempt to attract more Malaysians to save with them, so that dependency on debt can be reduced.

Replacing the culture of dependency on debt with a culture of saving for the children's future education will not be an easy feat. It will take a long time to bear fruit because the benefits will only be seen when today's school-aged children start enrolling into higher education many years down the road. With PTPTN being a frequently politicized issue, such a long-term strategy comes with a major political risk because some quarters will claim that nothing has changed in the interim. But proponents of this idea believe that reducing dependency on debt by encouraging education savings is one of the most important steps to take in preventing the PTPTN problem from continuing with no end in sight. They argue that the only way to reduce debt is by reducing the need for debt in the first place. Thus, even though the benefits may take a long time to materialize, they argue that the wait is worthwhile. 
iii. Put PTPTN under the Ministry of Finance: Another major structural change being proposed is to move PTPTN's supervision from the Ministry of Higher Education to the Ministry of Finance. Currently PTPTN is seen as an education agency that is responsible for ensuring equitable access to higher education, and this is why it is placed under the Ministry of Higher Education. But some quarters believe that the mountain of debt that PTPTN sits under today is because it has been managed as an education agency with a social purpose, when in reality, it is a financial institution that has firstly financial responsibilities, but happens to work in the education sector.

Transferring PTPTN's "home" to the Ministry of Finance will ensure that it is supervised by people with better expertise and clearer motivation. The move may sound easy to implement but it can be expected that there will be plenty of bureaucratic hurdles to be overcome. No ministry likes the idea of losing one of its agencies, especially if the agency is as big and important as PTPTN. At the same time, there is no guarantee that the Ministry of Finance will accept an entity with such a large debt with open arms either.

iv. Revise PTPTN's lending criteria: PTPTN needs to significantly revamp its lending criteria. As described earlier, the current policy at PTPTN is to make the lending processes easy. As a result, almost 95 per cent of those who apply will get their loan. ${ }^{28}$ No attention is given to the probability of the applicant absconding from their responsibility to repay in the future, or even the employment potential of the applicant. However, PTPTN does have detailed data showing the repayment rate of borrowers based on the courses they took at university. The proposition therefore is for PTPTN to stop providing loans to applicants enrolling into courses that are known to have low repayment rate, because graduates from those courses are assumedly not as employable as others.

\footnotetext{
${ }^{28}$ Internal PTPTN estimate.
} 
Revamping the lending criteria is most controversial because it means PTPTN will be actively involved in indirect social engineering, since it will inadvertently be channelling students into certain courses and diverting them away from other courses, without regard for what the students really want to do, what field they may excel in or the market demand at the time. Forcing students to ignore their academic interest and to choose instead courses that can be funded by PTPTN raises a moral dilemma among policymakers. But it is also seen as a logical step for an institution like PTPTN to take, because the possibility of repaying decreases if the borrower takes a course that results in unemployment after graduation.

Another controversy comes from the fact that this change will have a major effect on operators of private colleges and universities. Currently the operators are already required to obtain an operating licence from the Ministry of Higher Education as well as accreditation for their courses from the Malaysian Qualification Agency. If PTPTN were to dictate that some courses will not be funded despite students' interest in them, this will signal to the operators that their licence and accreditation are not sufficient. Questions can be raised about PTPTN's ability, or even credibility, to judge the quality or worthiness of a course that has already been accredited by the Malaysian Qualification Agency. And if PTPTN were to go ahead and change their lending criteria, some private institutions or even some departments at government institutions may experience a sudden drop in students to the extent that they may have to close. This raises a whole different set of challenges in terms of possible unemployment for the current staff and other related socio-economic impacts.

While the internal debate continues about the bigger revamp that needs to be done to reform PTPTN, one major step forward to complete the fulfilment of the PH manifesto was actually achieved in early 2020. On 2 January 2020, Prime Minister Mahathir Mohamad sacked the Minister of Education Maszlee Malik. Mahathir was then appointed by the Cabinet as Acting Minister of Education, and PTPTN successfully secured Mahathir's blessing to once again present their proposal for a 
new repayment mechanism that will allow the RM4,000 promise to be implemented. PTPTN was also able to secure support from the Minister of Finance to cover any funding gap arising from this step.

With support from both Mahathir and Minister of Finance Lim Guan Eng, PTPTN's Chairman was invited to table his proposal directly to the Cabinet on 19 February 2020. This made the discussion a lot smoother as all the hierarchical and bureaucratic hurdles from the Ministry of Education that previously prevented PTPTN from accessing the Cabinet was completely removed. As a result, PTPTN's proposal was endorsed by the Cabinet with very minor adjustments. Subsequently, it was planned that the Prime Minister, the Minister of Finance, and the Chairman of PTPTN would announce the new repayment mechanism on 3 March 2020, thereby fulfilling all the four manifesto promises around PTPTN.

Unfortunately, a major political crisis unfolded on 23 February 2020 which resulted in the collapse of the $\mathrm{PH}$ government just the day after. ${ }^{29}$ When this paper was written, the fate of the proposal is not yet decided.

\section{CONCLUDING REMARKS}

At the time of writing, the final decision about PTPTN's future has not yet been taken. The ideas described in the previous section continue to be debated. With the collapse of the PH government in February 2020, a new decision must firstly be achieved within the Ministry of Higher Education, as the ministry responsible for PTPTN. It remains to be seen if the new government will still attempt to fulfil the RM4,000 promise, or if it will spend its energy on the bigger revamp that PTPTN really needs. The Minister of Higher Education will have to table a new proposal to the Cabinet, after gathering inputs from other ministries that have a stake in the issue, especially the Ministry of Finance and the Ministry of Youths and Sports. This process may take several months to conclude.

${ }^{29} \mathrm{https}: / /$ www.thestar.com.my/news/nation/2020/02/24/pakatan-harapan-govtcollapses (accessed 1 March 2020). 
Although there are two schools of thought on how PTPTN can move forward - one pushing for operational changes while the other insists on adding structural reforms coupled with an attempt to change related cultural biases - it can be expected that the final decision will be an amalgamation of the various ideas that have been put forward. The challenges inherited by PTPTN are multifaceted and no one step will be its panacea. For example, it is clear that the most pressing operational challenge is PTPTN's low repayment rate. But tackling this issue will not alter PTPTN's current financial trajectory if it continues to lend using the current policy of giving approvals without regard to an applicant's potential to repay. And if the lending criteria were to be changed, the government must have sufficiently strong political will to face criticisms, because the number of beneficiaries will decrease and there are also risks of a backlash from private college and university operators. Most importantly, the wider economic structure of the country must also change so that borrowers earn a higher amount post-graduation. This is not something that PTPTN itself can act upon as it requires concerted efforts from the whole of government. But unless it happens, the problem of borrowers not earning enough will never be resolved.

It would not be wrong to say that the key to solving PTPTN's dilemma is political will. Many of the needed changes will not be immediately popular, because the benefits will take time to materialize. The government must be brave enough to weather the short-term political storm in order to bring long-term gain to the country. If the government continues to prioritize popularity, then taking principled actions will be difficult. But if the top political leaders can come to a consensus to bite the bullet for the greater good, then PTPTN may see light at the end of the tunnel.

Either way, the most important lesson for the whole PTPTN saga, ironically, is not in the how and when the reform is to be done. Rather, the biggest lesson is that a government, any government, should be very cautious when setting up an entity like PTPTN in which a social purpose such as education equity is sought to be achieved by creating a supposedly commercial venture under government ownership. In other words, PTPTN is a clear example of why a government should not be involved in business. If the government wanted to provide higher 
education funding at a discounted rate, then it should have done so through a government agency designed as a welfare scheme provider, not by creating an entity like PTPTN that is supposed to somehow use a commercial model to achieve a social purpose.

The PTPTN debt time bomb is the result of an attempt to build a commercial entity that obtains its funds from the financial markets to fulfil the government's social obligation to fund students into higher education. It ends up being an entity that is neither a commercial outfit nor a welfare agency. Worse, it is also an unsustainable entity saddled with an irrational business model. But it is now too late to criticize a decision taken twenty-two years ago. The mountain of debts that PTPTN has is a reality that must be solved by today's policymakers, long after those who started the problem have left the scene. 